\title{
"Y'ALL KILLED HIM, WE DIDN'T" Jewish Self-Hatred and The Larry Sanders Show
}

\section{Vincent Brook}

University of Southern California

Did the Jews invent self-hatred? A case can be made-from the production and the reception end. Centuries before they were branded collective Christ killers in the Gospel of St. Matthew, a calumny that laid the groundwork for both anti-Semitism and Jewish self-hatred, Jews themselves had planted the seeds of self-hatred for all humanity in the Garden of Eden. The biblical God's banishment of the ur-couple from Paradise inflicted a primordial self-loathing that would prove, at least for the faithful, all but inexpungable. Then there's the Jewish Freud, whose non-denominational take on Original Sin postulated a phylogenic and an ontogenic source: the collective killing of the Primal Father and the individual Oedipal complex. Freud's daughter Anna, meanwhile, gave self-hatred back to the Jews through her concept of "identification with the aggressor," which, while applicable universally, derived specifically from the observations of Jewish children who had survived Hitler Germany and yet identified positively with their Nazi persecutors and negatively with themselves as Jewish victims. Last not least, the poet laureate of existential angst, Franz Kafka, historicized selfhatred, laying the theoretical and experiential groundwork for what Jewish filmmaker Henry Bean calls "the ambivalent, self-doubting, self-hating modern condition."

To ascribe a privileged role for Jews in the encoding and decoding of self-hatred is certainly not to deny other groups' significant enmeshment in the process. Just as Jews have introjected anti-Semitism, people of color, women, gays, and lesbians have internalized the damaging social messages of racism, misogyny, and homophobia, directing against themselves the projected hatred of the normative society.

Jews, as a religious or ethno-racial grouping, do appear to have the most historically overdetermined claim to self-hatred, an overdetermination that is reinforced by a sometimes virulent internecine strain. Internecine self-hatred refers to self-denigration imputed by one sub-group to another within the larger group, though it needn't be experienced as such by the sub-group to which it is imputed. This form of self-hatred also tends, at least for Jews, to be triple-pronged.

One prong is directed at those demeaning attributes externally produced and reproduced through stereotypes, such as the Judas, Wanderer, or Shylock. While justifiably held by the targeted group to be illusory, constructed, or grossly exaggerated, these attributes nonetheless have had and may persist in having analogues in everyday life. As such, they have tended to be denied or avoided, thus leading, when such traits are encountered in the media or in social interaction, to the label "too Jewish." The second prong is reserved for those who attempt to avoid external stigmatization through adaptive strategies that confer acceptance within the dominant order. Exhibit A here is the Assimilated or Self-Denying Jew. While the "too Jewish" and "not Jewish enough" syndromes have their analogues among other oppressed groups, a third form of internecine self-hatred appears to be the exclusive province of Jews. Drawing on the historical memory and continued experience of antiSemitism as well as on the opportunities and pressures of assimilation, this form also 
is based in negative stereotypes. These stereotypes, however, have been generated primarily from within the Jewish community itself. Examples here range from the Schlemiel, Schlimazl and Nebbish of the Old World to the Neurotic Jew, Jewish Mother, and Jewish American Princess of the New. ${ }^{2}$

In twentieth- and twenty-first-century America, especially, the permutations of Jewish self-hatred in its external and internal manifestations have been unique. This uniqueness derives not only from the expression of Jewish self-hatred despite, and because of, the preponderance of Jews in the U.S. entertainment industries. It also relates to the integral role self-hatred has played in the formation of what many regard as Jews' greatest contribution to American popular culture-comedy, be it in vaudeville, the movies, night clubs, radio or television.

As Ruth Johnston just reminded us, Freud, in his Jokes and Their Relation to the Unconscious, located an explicitly Jewish self-critical component in the joke whereby "the mocker [the joke teller] participates in the defect being mocked [the butt of the joke]." ${ }^{3}$ This self-deprecatory aspect is often sited as the mainstay of Jewish humorand, by influence and extension, of minoritarian humor in general-and its function as a self-defense mechanism is patently evident. However, rather than functioning primarily as a mode of perseverance-laughing to keep from crying-as humor has for other minorities, for Jews humor has operated additionally as a mode of survivallaughing to keep from dying.

Albert Goldman has analyzed the origins and applications of survivalist Jewish humor in the Brooklyn-bred comics who invented stand-up comedy: Milton Berle, Shecky Green, Lenny Bruce, et al. These comedians' particular mode of satire, according to Goldman, was born in rejection of their immediate Jewish-immigrant families, neighborhoods, and milieus. But instead of "swallowing or disguising their [negative] emotions, these young Jews-consumed with self-hate or shame-came out in the open and blasted the things that hurt them." ${ }^{4}$ By turning a perceived weakness into a weapon, such volatile humor served to assuage self-hatred by both acknowledging its source and distancing the comics from it, while also offering protection from the source's career-, and potentially life-, threatening consequences.

In the post-World War II/post-Holocaust era, as overt anti-Semitism in the U.S. receded dramatically and government policies and Jews' own upward mobility encouraged widespread Jewish entry into the white middle class, self-hatred as a foundation for Jewish humor may well have declined but, as I will show, it has by no means disappeared. My focus is on the highly acclaimed, quintessentially postmodern sitcom The Larry Sanders Show, which aired on HBO from 1992-1998. ${ }^{5}$ The show, which melds reality and fiction, stars real-life stand-up comic and talk-show host Garry Shandling as a talk-show host in a perpetual panic about his ratings, his sex life, and his "too-large" lips and buttocks.

The emphasis on "over-sized" lips and buttocks, especially, is telling. Both labial and posterior profusions are generally associated with African Americans-more specifically, with Blacks' alleged hyper-sexuality. The association of Jews and Blackness is not a recent phenomenon. As Sander Gilman points out, "Medieval iconography always juxtaposed the black image of the synagogue, of the Old Law, with the white of the church." In the nineteenth century, the Jewish-Black connection was made into 
biological "fact" by "scientific" racists who explained Jews' preternatural status as a "mongrel race" through "the admixture of Negro blood with Jewish in the Diaspora of Alexandria," and who described American Jews, with their "sallow carnation complexion, thick lips, [and] crisped black hair," as the closest thing to the American mulatto. ${ }^{7}$

Whether today's TV viewer takes Larry Sanders for a "Black Jew," or a "White Negro," is not the issue here; rather, my interest is with the implications, for the genealogy of Jewish self-hatred and Jewish humor, of an aversion to traits associated with both Jews and another "other." And the aversion is not limited to only one "other"; ambivalent relations between Jews and gays are also abundantly cross-referenced on The Larry Sanders Show. Theoretically, as with Jews and Blacks, the Jewish/gay bond is a "natural" fit. The Jewish male's "resemblance to the homosexual" through physical imputations of effeminacy was one of the main "pathological" symptoms attributed to Jews by "scientific" racism. Equally pertinent, and more grounded in reality, is the historical "affinity with the closet" that the Jewish and gay subcultures have shared. Both the discursive and the historical aspects of Jewish-gay interaction are satirized in The Larry Sanders Show. ${ }^{8}$

Virtually every main character, including Larry, is subjected to at least one embarrassing moment regarding his perception as being gay. The culmination of this trope occurs when the talk-show's chief writer, Phil, the most brazenly homophobic of the lot, ends up acknowledging his own repressed homosexuality when he falls for the openly gay secretary, Brian, whom he had been harassing. Before their climactic embrace in the studio offices, the gay-Jewish connection was made explicit when the trouble-shooting producer, Artie, warned Phil about the potential damage to his career of his gay-bashing. Artie: "You know who runs this town?" Phil: "The Jews." Artie: "No, the gay Jews!"

Beyond what they reveal about the intersection of Jewishness, race, and sexuality, the show's Jewish-Black and Jewish-gay approach-avoidance complexes go a long way to explaining Larry Sanders' highly overdetermined Jewish self-hatred. For unlike sitcoms like Seinfeld, where Jewish self-loathing is more discursively inferred than openly expressed, or Curb Your Enthusiasm, where it has been named but steadfastly disowned, Larry Sanders' self-hatred is worn on his sleeve-though, notably, not with a Star of David attached. Actor Janeane Garofalo, for example, who had a regular part as the show-within-the-show's talent booker, describes Larry's condition generically: "He's so full of self-loathing, it's just hilarious. He's so full of sheer self-hatred it's a pleasure to watch." ${ }^{9}$ No mention here of the specifically Jewish nature of Larry's self-hatred. Indeed, for the occasional viewer, his condition's Jewishness might easily remain a mystery, as might Larry's Jewish identity altogether.

The closeting of Jewishness has a long history in American entertainment, from the nose-straightening, hair-dying, and name-changing of Jewish movie stars to the non-denominationality of TV performers such as George Burns (nee Nathan Birnbaum) and Jack Benny (nee Benjamin Kubelsky). What distinguishes Larry Sander's Jewish selfdenial is, first, that it occurs at a time when most other Jewish TV performers-e.g., Jerry Seinfeld, Richard Lewis, Fran Dresher, Jon Stewart, Larry David-were "coming out" Jewish; and second, that the self-denial is diegetically informed. 
You have to look hard to pick up the clues, however, for Larry Sanders fastidiously, and at all cost, avoids the subject. The only way to determine Larry's ethnicity, besides inferring it from his appearance or from extratextual or intertextual associations with Garry Shandling, is to have caught one of the two episodes (out of a total of eighty-nine) that directly confront the issue-or to have attended, as I did, the 2004 "Creating Comedy" panel sponsored by the Museum of Television and Radio in Beverly Hills. During the Q \& A, I asked the panel of mainly Jewish TV writers, which included Garry Shandling and Larry Sanders Show writer Judd Apatow, what part their Jewishness had played in their creative work. After the nervous uproar caused by my question had subsided, Everybody Loves Raymond creator Phil Rosenthal broke the ice: "What part has it played? Not one shtickle!" When the laughter greeting this Yiddishism had died down, Apatow confided that the Larry Sanders writers had debated behind the scenes about whether Larry was Jewish and had concluded that he was a self-hating Jew.

As for the two episodes that affirm Apatow's claim, the first features comedian Brett Butler playing "herself" as a talk-show guest. In response to Larry's reference to the success of her recent best-selling book, Butler opines that after buying a house for her mother with proceeds from the book, "everything you do with your money is okay." "You don't have any guilt," Larry continues her thought. Butler: "I'm a WASP." Larry: "WASP's don't have guilt, do they?" To which Butler retorts with a wry smile and her Southern drawl: "Y'all killed Him, we didn't!" Larry bows his head embarrassedly amidst the in-house audience's nervous laughter, as the show-within-the show cuts to commercial.

The second episode similarly conflates Larry's closeted Jewishness with its selfhating component. The spark here is Larry's desperate need to make People magazine's "Ten Sexiest Men" list, even if it means bumping talk-show guest, and friend, Ben Stiller off the list. Stiller finds out about the dirty trick and, while he remains friendly during the talk-show interview, angrily confronts Larry behind the scenes. Feigning innocence, Larry tells the irate Stiller: "If you could see how Jewish you look!" Stiller snaps back, "Oh, that's great! Coming from a self-hating Jew like yourself!"

One can hardly conceive a more succinct delineation of the origins and manifestations of Jewish self-hatred than these two sitcom moments provide. The one highlights the condition's anti-Semitic underpinnings in the Christ-killing myth, the second illustrates its internecine expression in reaction to assimilation and self-denial. Larry Sanders emerges "guilty" on both counts. A third aspect, relating to selfpreservation in the traditionally-yet still highly defensive-“Jewish" entertainment industry, is foregrounded in another episode, "My Name is Asher Kingsley." Here the issue is approached from two different angles, one related to Larry, the other to Larry's talk-show sidekick and the series' comic foil, Hank Kingsley (played by Jeffrey Tambor). ${ }^{10}$ Both aspects intersect with the notion of self-preservation.

The episode opens with Hank's abrupt decision to reclaim his Jewishness, starting by affixing a mezuzah beside his office door and changing his stage name back to his birth name, Hank Lepstein. Referencing the self-preservation motif, Hank explains, "I've hidden it [my Jewishness] all my life. First in school so I wouldn't get beat up. Then in show business so I wouldn't alienate my public. . . I I want to regain 
my faith, I want to rejoin my people!" ${ }^{11}$ It turns out that Hank's motives, as usual, are hardly pure: his real reason for coming out Jewish is to seduce Rabbi Klein, an attractive female rabbi he met at Marvin Hamlish's synagogue. In a vain attempt to dissuade Hank from his conversion, Artie reinforces the self-preservation theme with a gentile twist: "You know, l've worked for your people a long time. They run this town. They've run it a hell of a lot better than the agents. . . But we're just trying to entertain people and morality's just gonna get in the way." ${ }^{11}$ The Jewish jokes come fast and furious. When Larry's Black secretary, Beverly (Penny Johnson), complains because Hank is allowed to give his rabbi a tour of the studio when her pastor wasn't afforded the same privilege, Hank defends the double standard: "I think you'll agree that a rabbi fits more nicely into a show business environment." Phil, also a non-Jew, questions whether Hank is really Jewish because he had previously seemed to deny it. "People change," Hank insists; "it's called spiritual growth." Phil: "Well, this is called spiritual disbelief, because most Jewish people I know are smart!" As for the connection to Larry, Artie cautions Hank about bringing the rabbi around the set because "religion makes Larry very uncomfortable." The topper comes when Hank surprises everyone by putting a yarmulke on during the talk show. During commercial break, after being scolded by Larry for his unscripted embarrassment, Hank asks Larry about his religion, which Hank hasn't the slightest idea about even though he has known Larry for fifteen years. "That's a private matter," Larry mutters evasively, though he tells Hank that his cap is on inside out. Artie adds in an aside, "His religion is talkshow host." 12

A subsequent backdoor meeting between Hank and two network executives expands on Artie's aside, while putting the kibosh on Hank's religious fling. "They [the network] want our appeal to be non-denominational," one of the execs explains. ${ }^{13}$ "But you're Jewish, aren't you, Stu?" Hank protests. Updating the assimilationist adage "A Jew at home, a gentleman on the street," Stu responds, "Yes, but I'm behind the camera where the viewing public can't see me." The meeting ends with Hank calling Stu an Uncle Tom and Stu calling Hank a schmuck. Hank, as usual, ultimately sacrifices personal principle for self-preservation, the urgency of which is underscored by the hate mail he receives. A swastika is scrawled on one envelope and another letter reads, "Dear Jew: Keep wearing your Jew hat so I can use it as a target when I blow your Jew head off!" When a third correspondent threatens to stop buying the brand of orange "jews" Hank peddles, it's off with Hank's kippah-an opportunistic gesture that turns out to be redundant. For Hank had already been de-capped during the talk show by Artie's order to shoot him in choker close-ups that cropped his objectionable headgear!

When all the Jewish jokes are added up, this last one appears to crystallize the episode's, if not the series', overarching Jewish theme: If you want to survive in the entertainment business, much less in public life, don't let your kippah-i.e., your Jewishness-show. In the "Creating Comedy" panel alluded to previously, Garry Shandling extrapolated just such a theme from the "My Name is Asher Kingsley" episode. Drawing on Artie's aside about Larry, "His religion is talk-show host," Shandling suggested that talk-show hosts don't want to divulge their religion because they want to appeal to as broad a spectrum of the audience as possible: "They're everyman." 
In a personal interview, Larry Sanders Show co-creator Dennis Klein was more ethnically specific: "Larry Sanders was conceived as the very antithesis of Jewishness. The Johnny Carson Show, for example-on which Larry patterns his show and himself as a talk-show host-was, in its background and approach, intended by Carson as a rebuke to mainstream Jewish comedy." Eager to dismiss his show's associations with Jewishness, however, Klein quickly added that "Larry Sanders was not intended as a satirical comment on the hyper-gentile, anti-Jewish aspect of Carson's show." Perhaps not, but the "anti-Jewishness" seeps through. . . .

In conclusion, The Larry Sanders Show demonstrates that Jewish self-hatred, and its representation in Jewish humor, remains subject to what Gilman calls selfhatred's "inevitable double bind." On the one hand, Jews, in order to succeed in society, are forced to assimilate; but in so doing they must also reject as unworthy an aspect of themselves. On the other hand, anti-Semites reject conspicuous Jews yet also suspect those who manage to "pass" as having done so under false (read:

conspiratorial) pretences. ${ }^{14}$ Jews, quite literally, are damned if they do and damned if they don't, and-when internecine self-hatred is added to the mix-the double bind is doubled yet again.

Internecine self-hatred has been exacerbated, most recently, by the Jewish survivalist crisis and conflicting attitudes toward Israel. With the intermarriage rate surpassing $40 \%$ in the 1990 s and approaching $50 \%$ by the 2000 s, and with religious observance and child-rearing also in decline, the combined trend has been called a "Silent Holocaust" by some Orthodox survivalists. ${ }^{15}$ The actual Holocaust, meanwhile, remains one of the most palpable postmodern sources for Jewish self-hatred, no longer so much through "identification with the oppressor" as through shame at the alleged passive submission of Jews to the Final Solution. The Tough Jew of modern-day Israel and the Jewish Defense League epitomizes psychosocial resistance to the "Jewish weakling" syndrome. The most potent new source of internecine Jewish self-hatred is post-1967 Israel itself-mainly in regard to the Palestinian issue. The "good" Jew/"bad" Jew dichotomy that previously pitted Ostjuden vs. Westjuden, ${ }^{16}$ now characterizes an equally voluble conflict in which Orthodox vs. secular beliefs and pro- vs. anti-Israeli government sentiments are regarded alternately as badges of honor or disgrace. Jewish self-criticism, a long-honored Jewish tradition, which, in the face of heightened antiSemitism in late nineteenth-century Europe, transmogrified into the Jewish "pathology" of self-hatred, has become an endangered species once again. This time, however, the transmogrification has been effected by Jews themselves. ${ }^{17}$ Stuck between images of a wimp (the Holocaust) and a storm trooper (Israel), Jews seem more mired in internecine self-hatred than ever before, with-as was demonstrated in the killing of Prime Minister Yitzhak Rabin by an ultra-Orthodox Jew-potentially lethal consequences. ${ }^{18}$

In the end, as it has been throughout post-Emancipation Jewish history, the most effective way to deal with this dilemma may be through transformative humor, humor that helps to loosen, perhaps even to break through, the multiple double-binds of Jewish self-hatred. To further test this hypothesis, let the last word go to The Larry Sanders_Show, which in one of its most postmodern "Jewish moments" uses the selfreferential logic of media representation to deconstruct the torturous illogic of the "Jewish question." In the episode, comic Jon Stewart, as himself, and acting as Larry's talk-show-host substitute, does a sketch lampooning the game show Jeopardy that functions as a limit case for the "return of the repressed." Called "The Adolph Hankler 
Show," it features Hank as Adolph Hankler, the game-show host, dressed in a Nazi uniform and wearing a Hitler mustache. The correct "question" to all of Hankler's "answers" - such as "They caused the sinking of the Titanic" and "The small people that controls the world's money supply"-is, uniformly of course, "Who Are the Jews?" When the non-Jewish Artie complains about the offensiveness of the sketch, Stewart responds, "Yeah well, it doesn't bother me, and I'm Jewish." "So was Jesus," Artie fires back, "and look where he ended up?" "On the WB," Stewart retorts. ${ }^{19}$

\section{Notes}

This paper is an abridged and slightly revised version of an essay of the same title in Vincent Brook, ed., You Should See Yourself: Jewish Identity in Postmodern American Culture (New Brunswick, N. J.: Rutgers University Press, 2006), 298-317.

\footnotetext{
${ }^{1}$ Henry Bean, “The Believer": Confronting Jewish Self-Hatred (New York: Thunder's Mouth Press, 2000$), 19$. ${ }^{2}$ Sander Gilman, Jewish Self-Hatred: Anti-Semitism and the Hidden Language of the Jews (Baltimore: Johns Hopkins University Press, 1986),

${ }^{3}$ Quoted in Elizabeth Jane Bellamy, Affective Genealogies: Psychoanalysis, Postmodernism, and the "Jewish Question" after Auschwitz (Lincoln: University of Nebraska Press, 1997), 96. See also Ruth D. Johnston, "Joke-Work: The Construction of Jewish Postmodern Identity in Postmodern Theory and American Film," in You Should See Yourself: Jewish Identity in Postmodern American Culture, ed. Vincent Brook (New Brunswick, N. J.: Rutgers University Press, 2006), 207-229.

${ }^{4}$ Albert Goldman, "Boy-Man Schlemiel: The Jewish Element in American Humor," in Albert Goldman, Freakshow (New York: Antheneum, 1971), 174-178; 178.

${ }^{5}$ In regard to the show's critical acclaim and influence on subsequent television, see, for example, Robert Lloyd, “'Pilot' Flies in the Face of Convention," Los Angeles Times, September 5, 2004: E12; Jacques Steinberg, "Hey Now: It's Garry Shandling's Obsession," New York Times, January 28, 2007: AR1, 36; Robert Lloyd, "When is a DVD not just a DVD?" Los Angeles Times, April 15, 2007: E20-21.

${ }^{6}$ Gilman, Jewish Self-Hatred, 7.

${ }^{7}$ The first quote, from Houston Stewart Chamberlain, is in Gilman, Jewish Self-Hatred, 7; the second, from Adam Grotowski, is in Gilman, Jewish Self-Hatred, 8.

${ }^{8}$ For more on discursive links between Jews and gays, see Sander Gilman, The Jew's Body (New York; Routledge, 1991); Naomi Seidman, "Fag Hags and Bu-Jews: Toward a (Jewish) Politics of Vicarious Identity," in Insider/Outsider: American Jews and Multiculturalism, ed. David Biale, Michael Galchinsky, and Susannah Heschel (Berkeley: University of California Press, 2000), 254-268; Daniel Boyarin, Unheroic Conduct: Jewish Masculinity (New York: Oxford University Press, 1998); Daniel Boyarin, Daniel Itzkovitz, and Ann Pellegrini, eds., Queer Theory and the Jewish Question (New York: Columbia University Press, 2003).

${ }^{9}$ Quoted in Jay Martel, “True Lies,” Rolling Stone, September 8, 1994: 66.

10 Tambor had a featured role in Arrested Development, as the incarcerated patriarch of a wealthy, hyperdysfunctional Westside Los Angeles Jewish family.

${ }^{11}$ Shandling, at the "Creating Comedy" panel, related that while growing up in Tuscon, Arizona, he had been beaten up because of his Jewishness.

${ }^{12}$ The absurdist irony of separating agents from the "Jewish-run" entertainment industry cannot have been lost on the show-biz-savvy Artie, nor on the (Jewish) writers of the episode.

${ }^{13}$ At least this is how Apatow recalled the end of the scene at the panel, perhaps from the original HBO episode. Artie's comment is not included in the Bravo rerun, which had been edited down for a shorter time slot.

${ }^{14}$ Sander Gilman, "Jewish Self Hatred (I) and The Believer (II)," in Henry Bean, "The Believer", 221-242; 238; Gilman, The Jew's Body, 19.

${ }^{15}$ The 1990 Jewish National Population Survey (JNPS) initially reported a 52\% intermarriage rate since 1985. Sociologist Steven Cohen and others subsequently revised the figure downward to between 42 and 43\% (J.J. Goldberg, Jewish Power: Inside the American Jewish Establishment [Reading, Mass.: AddisonWesley, 1996], 66-68). The 2000 JNPS, working from the revised 1990 figure, showed a steady rise in intermarriage to 47\% from 1990 (Joe Berkofsy, Los Angeles Jewish Journal, 12 September 2003: 20). For more on the intermarriage issue, see McClain, Embracing the Stranger Intermarriage and the Future of the American Jewish Community (New York: Basic Books, 1995); Susan Weidman Schneider, Intermarriage: The Challenge of Living with Differences between Christians and Jews (New York: The Free Press, 1989).
} 
${ }^{16}$ Gilman, "Jewish Self-Hatred," 227-234.

17 Gilman, "Jewish Self Hatred," 221. For a brilliant conflation of the Holocaust- and Israel-based strands of Jewish self-hatred, see Henry Bean's film The Believer (2002) and Bean's book The Believer: Confronting Jewish Self-Hatred, which contains the film's shooting script and commentary by the filmmaker and various scholars.

${ }_{18}$ This dichotomy is drawn from a scene in the film The Believer. When the American Jewish protagonist, a self-hating neo-Nazi based on an actual historical figure, rants against Jews of the Holocaust and those of modern-day Israel, a Jewish friend retorts, "Do you hate them because they're wimps or because they're storm troopers?"

${ }^{19}$ The WB refers to the Warner Brothers television network, founded in 1995, which in 2006 merged with the United Paramount Network (UPN) to form the CW network. One of the most popular shows on the WB was the Christian-themed drama Seventh Heaven. 